\title{
PERANCANGAN SISTEM INFORMASI GEOGRAFIS PENYEBARAN PENYAKIT DEMAM BERDARAH DENGUE DI WILAYAH JOMBANG
}

\author{
Novi Dwesty Bahtiar'), Agus Sifaunajah ${ }^{2)}$ \\ 1) Program Studi Sistem Informasi Universitas KH. A. Wahab Hasbullah \\ 2) Program Studi Ilmu Komputer Universitas KH. A. Wahab Hasbullah \\ Correspondence Author: agus.syifa85@gmail.com
}

\begin{abstract}
ABSTRACK
One of the most common cases of disease in Indonesia is dengue hemorrhagic fever. Jombang region is one of the areas whose people are infected with dengue fever because every year there must be cases and cases that occur is also high. Various efforts have been made to prevent the spread of the disease. Among the 3M program (Drain, Closing, and Bury), fumigation (fogging) in each area that is endemic DHF. But still there are victims, even increasing from the years. From these problems is also required system capable of providing relief. With this problem then built a Web-Based Geographic Information System that can help people to know the actual spread of dengue fever. Geographic Information System is a collection of computer systems that store, process, manipulate, analyze geography data into quality information related to geographic objects. Within the Geographic Information System itself there are two important elements of Geographic Data used as a reference for attribute data, and the attribute data itself used to support spatial or geographical information. The design of the map to be displayed in this application using Google Maps API, while the methodology in the development of this system using waterfall method that includes system analysis, system design, system implementation and testing. In making this Web-based Geographic Information System uses MySQL as database to store the required data and use PHP as the programming language. The purpose of making Geographic Information System is to help Jombang District Health Office in providing information to the community about the spread of dengue fever so that it can reduce the number of patients each year.
\end{abstract}

Keywords: Google Maps, GIS, Healthy, Dengue Fever. 


\section{PENDAHULUAN}

Sistem Informasi Geografis adalah sebuah aplikasi yang dikembangkan untuk memberikan data informasi berupa visualisasi. Menampilkan lembaran peta dalam sebuah monitor. Pengembangan aplikasi atau program sistem informasi geografis ini semakin hari terus berkembang pesat. Salah satu contoh penggunaannya dapat diketahui dari berbagai aspek. Contoh berikutnya dalam bidang kesehatan aplikasi penyebaran wabah penyakit demam berdarah dengu. Karena sulitnya proses sosialisasi kepada masyarakat secara langsung, dan ketertarikan masyarakat terhadap teknologi yang semakin berkembang. Maka dipilih sistem informasi geografis penyebaran penyakit demam berdarah dengue untuk membantu pihak terkait agar lebih mudah dalam penyempaian segala informasi tentang penyakit demam berdarah terutama dalam lingkup wilayah Jombang.

\section{KERANGKA TEORI}

\subsection{Landasan Teori}

Sistem Informasi Geografis adalah sebuah sistem informasi berbasis komputer dengan memakai data digital yang berhubungan dengan letak geografis di muka bumi dan memiliki 3 unsur pokok yaitu sistem, informasi, dan geografis. Istilah sistem informasi geografis mengandung pengertian informasi mengenai letak-letak yang ada di permukaan bumi, pengetahuan mengenai posisi suatu obyek dan informasi mengenai keterangan-keterangan (atribut) yang terdapat dipermukaan bumi yang dapat diketahui posisinya diketahui. Sistem tenformasi geografis yang terdiri dari sistem komputer, data geospatial, dan user. Sistem informasi geografis mempresentasikan real word (dunia nyata) diatas monitor komputer seperti lembaran peta yang dapat mempresentasikan dunia nyata diatas kertas, akan tetapi mempunyai kekuatan lebih dan fleksibilitas dari pada lembaran kertas (Kurniawan, 2014)

Penyakit Demam Berdarah Dengue (DBD) pertama kali dilaporkan di Surabaya pada tahun 1968. Penyakit DBD ini terus mengalami peningkatan dan menyebar bertambah luas. Seluruh wilayah Indonesia mempunyai risiko terjangkit penyakit ini. Hampir sepanjang tahun penyakit DBD ini selalu ditemukan di seluruh Indonesia terutama pada awal musim penghujan. Menurut Kementrian Kesehatan Republik Indonesia sampai dengan 28 Agustus 2014 jumlah penderita DBD sebanyak 48.905 kasus dengan kematian 376 (Teguh, P. 2015)

PHP adalah bahasa pemrograman script yang paling banyak dipakai saat ini. PHP banyak dipakai untuk memrogram situs website dinamis, walaupun tidak tertutup kemungkinan digunakan untuk pemakaian lain. Contoh terkenal dari aplikasi PHP adalah forum ( $p h p B B$ ) dan MediaWiki (software di belakang Wikipedia). PHP juga dapat dilihat sebagai pilihan lain dari ASP.NET/C\#/VB.NET Microsoft, ColdFusion Macromedia, JSP/Java Sun Microsystems, dan $C G I / P e r l$. Contoh aplikasi lain yang lebih kompleks berupa CMS yang dibangun menggunakan PHP adalah Mambo, Joomla!, Postnuke, Xaraya, dan lain-lain.

MySQL adalah sebuah perangkat lunak sistem manajemen basis data $S Q L$ (bahasa Inggris: databasemanagement system) atau DBMS yang multithread, multi-user, dengan sekitar 6 juta instalasi di seluruh dunia. $M y S Q L A B$ membuat $M y S Q L$ tersedia sebagai perangkat lunak gratis dibawah lisensi GNU General Public License (GPL), tetapi mereka juga menjual dibawah lisensi komersial untuk kasus-kasus dimana penggunaannya tidak cocok dengan penggunaan GPL. Relational Database Management System (RDBMS). MySQL adalah Relational Database Management System (RDBMS) yang didistribusikan secara gratis dibawah lisensi GPL (General Public License). Dimana setiap orang bebas untuk menggunakan MySQL, namun tidak boleh dijadikan produk turunan yang bersifat komersial.

MySQL sebenarnya merupakan turunan salah satu konsep utama dalam database sejak lama, yaitu SQL (Structured Query Language) My SQ1 merupakan database yang paling digemari dikalangan Programmer Website, dengan alasan bahwa program ini merupakan database yang sangat kuat dan cukup stabil untuk digunakan sebagai media penyimpanan data. Sebagai sebuah database Server yang mampu untuk memenejemen database dengan baik, MySQL terhitung merupakan database yang paling diminati atau digemari dan paling banyak digunakan dibandingkan database yang lainnya. Selain MySQL masih terdapat 
beberapa jenis database server yang juga memiliki kemampuan yang juga tidak bisa dianggap mudah, dengan contoh yaitu Oracle dan Postgre SQL. Dengan kata lain, MY SQL merupakan Perangkat lunak manajemen basis data SQL (database management system) atau DBMS yang multithread, multi-user, dengan sekitar 6 juta instalasi di seluruh dunia. MySQL AB membuat MySQL tersedia sebagai perangkat lunak gratis dibawah lisensi GNU General Public License $(G P L)$, tetapi mereka juga menjual dibawah lisensi komersial untuk kasus-kasus dimana penggunaannya tidak cocok dengan penggunaan GPL. Tidak sama dengan proyek-proyek seperti Apache, dimana perangkat lunak dikembangkan oleh komunitas umum, dan hak cipta untuk kode sumber dimiliki oleh penulisnya masing-masing, MySQL dimiliki dan disponsori oleh sebuah perusahaan komersial Swedia MySQL AB, dimana memegang hak cipta iasm atas semua kode sumbernya. Kedua orang Swedia dan satu orang Finlandia yang mendirikan MySQL AB adalah: David Axmark, Allan Larsson, dan Michael "Monty" Widenius. (Ramadhani, S. 2013)

\subsection{Pustaka Rujukan}

Pada penelitian yang dilakukan oleh Falianingrum,A (2012) dengan judul Perancangan WEB-GIS Penyebaran Wabah Penyakit Demam Berdarah Dengue (DBD) dan Malaria di Kota Bandar Lampung dengan metodologi sebagai berikut Tahap pertama pada perancangan WEB-GIS yaitu tahap survey dan pengumpulan data. Pengumpulan data penyebaran wabah penyakit Demam Berdarah Dengue (DBD) dan Malaria dilakukan di Dinas Kesehatan Kota Bandar Lampung, sedangkan data spasial dan atribut wilayah administrasi Kota spasial tersebut memiliki posisi koordinat Universal Transverse Mercator (UTM)

Pada penelitian kedua yang dilakukan oleh Athiyyah, U (2014) yang berjudul Aplikasi Sistem Informasi Geografis Penyebaran Penyakit Demam Berdarah Dengue Berbasis WEB Untuk menghasilkan aplikasi Sistem Informasi Geografis berbasis web ini dibutuhkan data kasus Demam Berdarah Dengue Kabupaten Kudus pada tahun 2007 sampai 2008 dan peta Administrasi yang digunakan untuk persebaran penyakit Demam Berdarah Dengue Kabupaten Kudus.

\section{METODOLOGI}

\subsection{Alat dan Bahan}

Bahan penelitian yang digunakan dalam proses penelitian ini berasal melalui studi pustaka, jurnal, artikel dan buku pendukung.

Dalam melakukan penelitian ini, alat yang digunakan untuk keberhasilan penelitian adalah sebagai berikut :

a. Perangkat Keras (Hardware)

Notebook advan P1N-46120 S dengan spesifikasi Prosesor Intel Pinetrail N455 1.66 Ghz, RAM 1 GB DDR3, Hard disk 200 GB.

b. Perangkat Lunak (Software)

Windows 7 Ultimate 32 bit, Xampp, MySQL, serta Ms. Office Word 2007.

\subsection{Prosedur Penelitian}

Penelitian ini merupakan penelitian pengembangan (development research) dengan maksud untuk mengembangkan pengetahuan tentang manajemen sains dalam aplikasi sistem informasi geografis penyebaran penyakit demam berdarah dengue

Metode penelitian untuk menyelesaikan permasalahan ini adalah sebagai berikut:

5. Studi literatur,

6. Bagan Alir penelitian

Adapun alur pengolahan data dapat dilihat pada gambar berikut : 


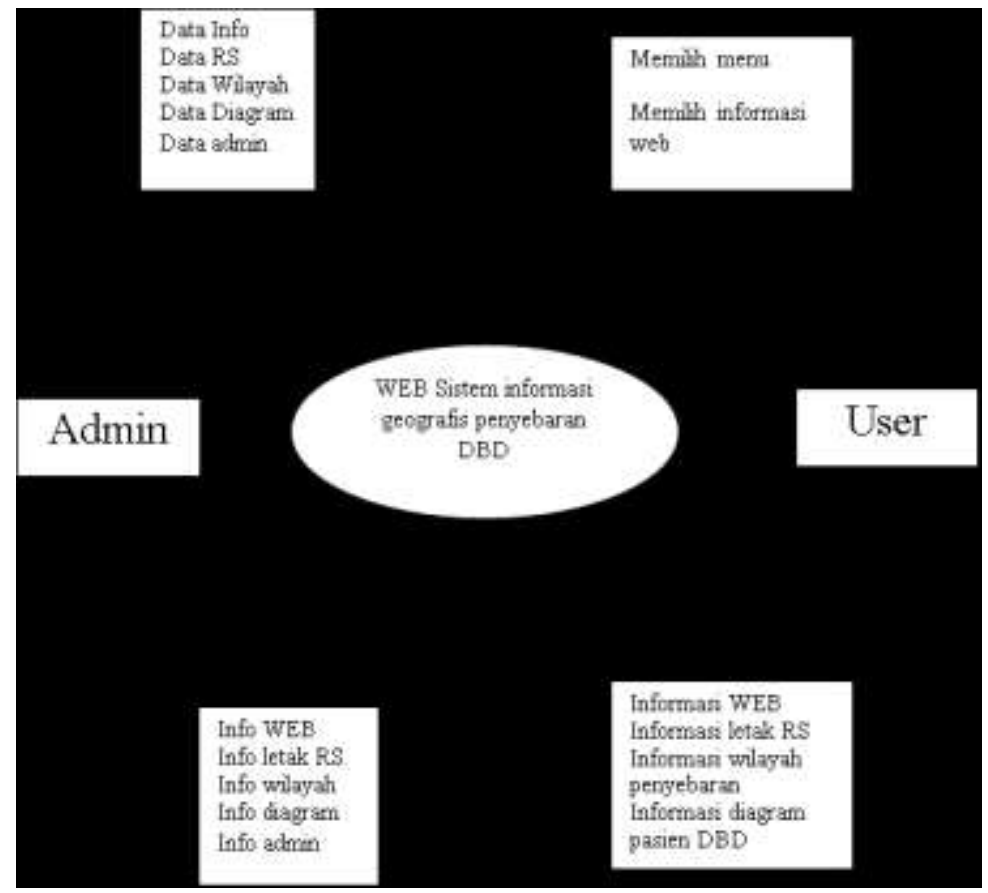

Gambar 1. Bagan Alir penelitian

\section{Hasil dan Pembahasan}

\subsection{Perancangan Interface Aplikasi}

Perancangan interface aplikasi Sistem Informasi Geografis Penyebaran Penyakit Demam Berdarah dengue. Adapun sebagian bentuk perancangan form yang dibutuhkan adalah sebagai berikut :

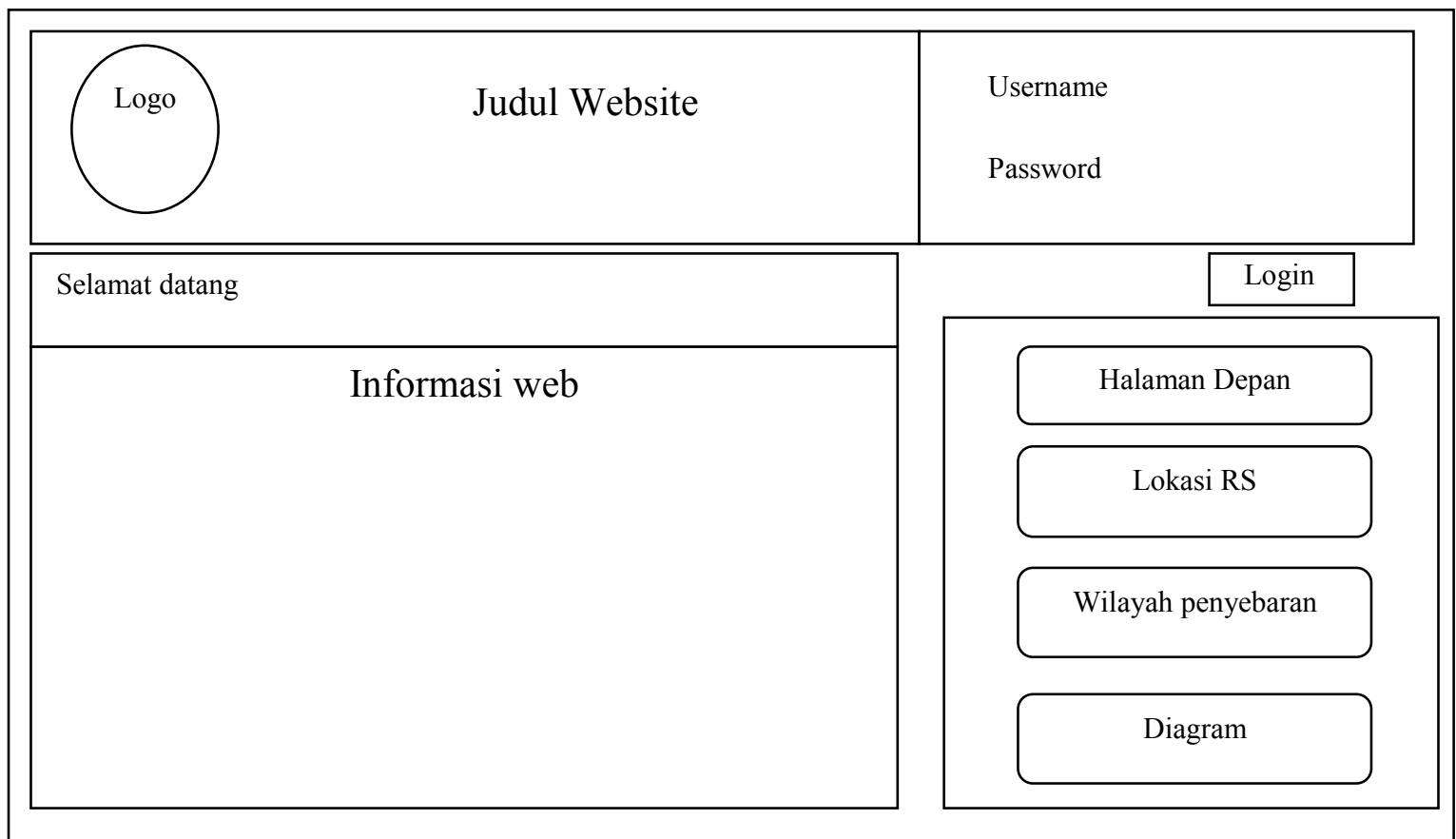

Gambar 1 : Perancangan Halaman Utama Website 


\subsection{Hasil Interface Aplikasi}

Setelah dilakukan perancangan interface, dilakukan pengujian untuk melihat apakah hasil perancangan dapat berjalan sesuai harapan. Adapun sebagian hasil yang didapatkan adalah sebagai

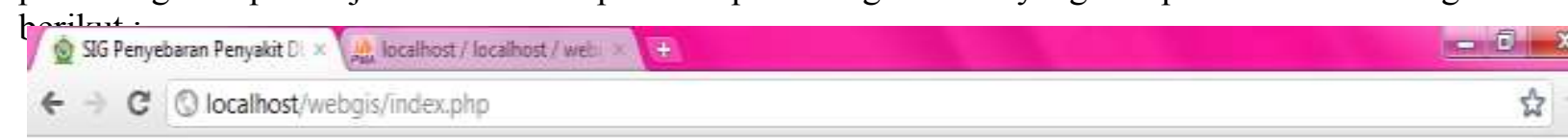

$\begin{gathered}\text { Sistem Informasi Geografis (SIC) } \\ \text { Penyebaran Penyakit DBD } \\ \text { Wilayah Kota Jombang }\end{gathered}$
Selamat Datang

\section{DEMAM BERDARAH DENGUE (DBD)}

Demam berdarah dengue (DBD) merupakan penyakt yang banyak ditemukan di sebagian besar wilayah tropis dan subtropis, terutama asia tenggara, Amerika tengah. Amerika dan Karibia. Host alami DBD adalah manusia, agentnya adalah vinus dengue yang termasuk ke dalam famil Flavindae dan genus Flavivirus, terdiri dari 4 serotipe yaitu Den-1, Den-2, Den3 dan Den4 ditularkan ke manusia melalui gigtan nyamuk yang terinfeksi, khususnya nyamuk Aedes aegypt dan. Aedes Albopictus yang terdapat hampir di selunuh pelosok indonesia. Masa inkubasi virus dengue dalam manusia (inkubasi intninsik) berkisar antara 3 sampai 14 har sebelum gejala muncul, gejala klinis ratarata muncul pada hari keempat sampai hari ketujuh, sedangkan masa inkubasi ekstrinsik (di dalam tubuh nyamuk) berlangsung sekitar 8-10 hari. Manifestasi kinis mulai dari infeksi tanpa gejala demam, demam dengue (DD) dan DBD, ditandai dengan demam tinggi terus menerus selama $2-7$ hari; pendarahan diatesis seperti ui toumiquet positif, trom-bositooenia dengan jumlah trombosit $\leq 100 \times 109, \mathrm{~L}$ dan kebocoran plasma akibat peningkatan permeabilitas pembuluh. Tiga tahap presentasi kinis diklasifikasikan sebagai demam, beracun dan pemulihan. Tahap beracun, yang berlangsung $24-48$ jam, adalah masa paling kritis, dengan kebocoran plasma cepat yang mengarah ke gangguan peredaran darah.Terdapat 4 tahapan derajat keparahan DBD, yaitu derajat I dengan tanda terdapat demam disertai gejala tidak khas dan uj tomikef + (positif); derajat II yaitu derajat I ditambah ada perdarahan spontan di kulit atau perdarahan lain, derajat III yang ditandai adanya kegagalan sirkulasi yaitu nadi cepat dan lemah serta penurunan tekanan nadi ( menerun sampai $<80$ mmHg), sianosis di sekitar molut, akral dingin, kulit lembab dan pasien tampak gelisah, serta derajat IV yang ditandai dengan syok berat (orofound shock) yatu nadi tidak dapat diraba dan tekanan darah tidak terukur

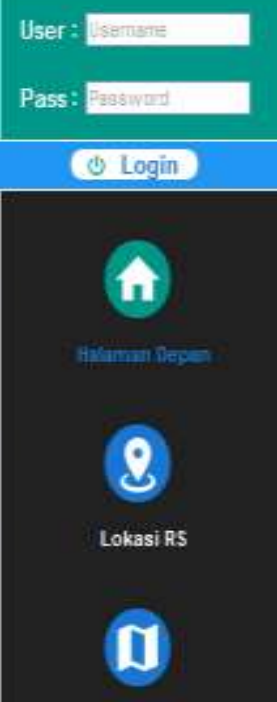

Wilsyah Peryebaran

Gambar 2 : Tampilan Form Utama

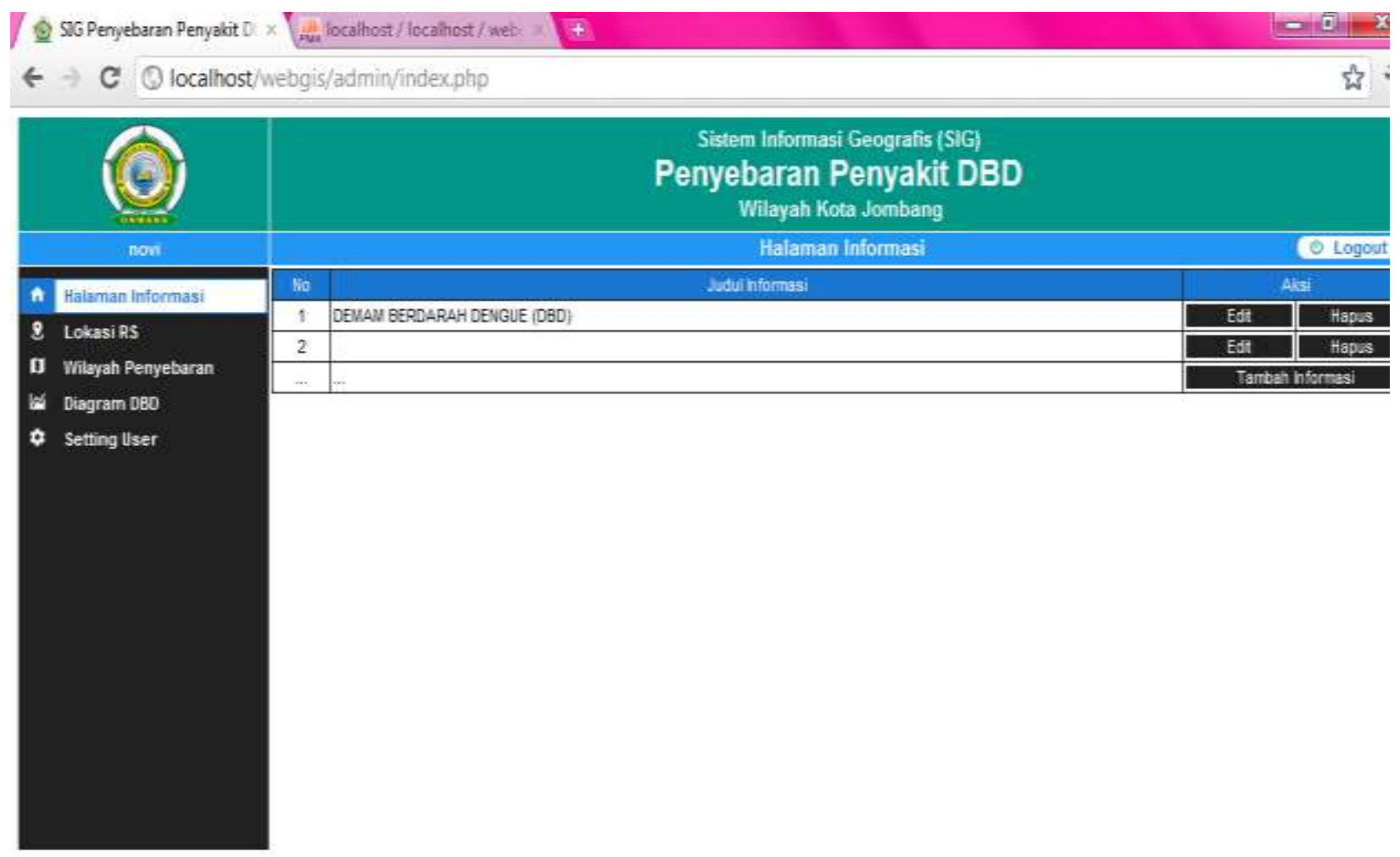

Gambar 3 : Halaman menu edit 


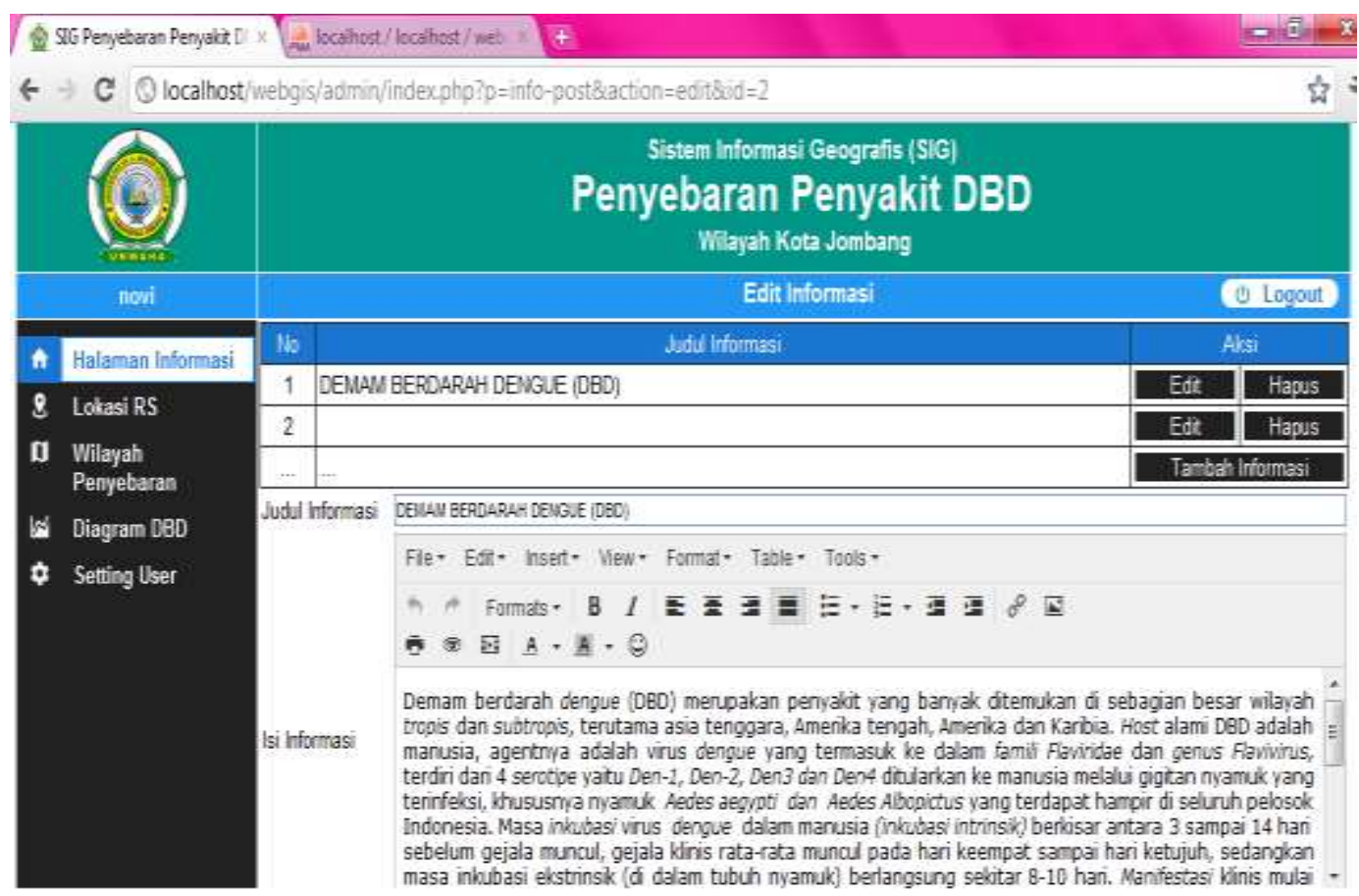

Gambar 4 : Halaman menu edit Informasi

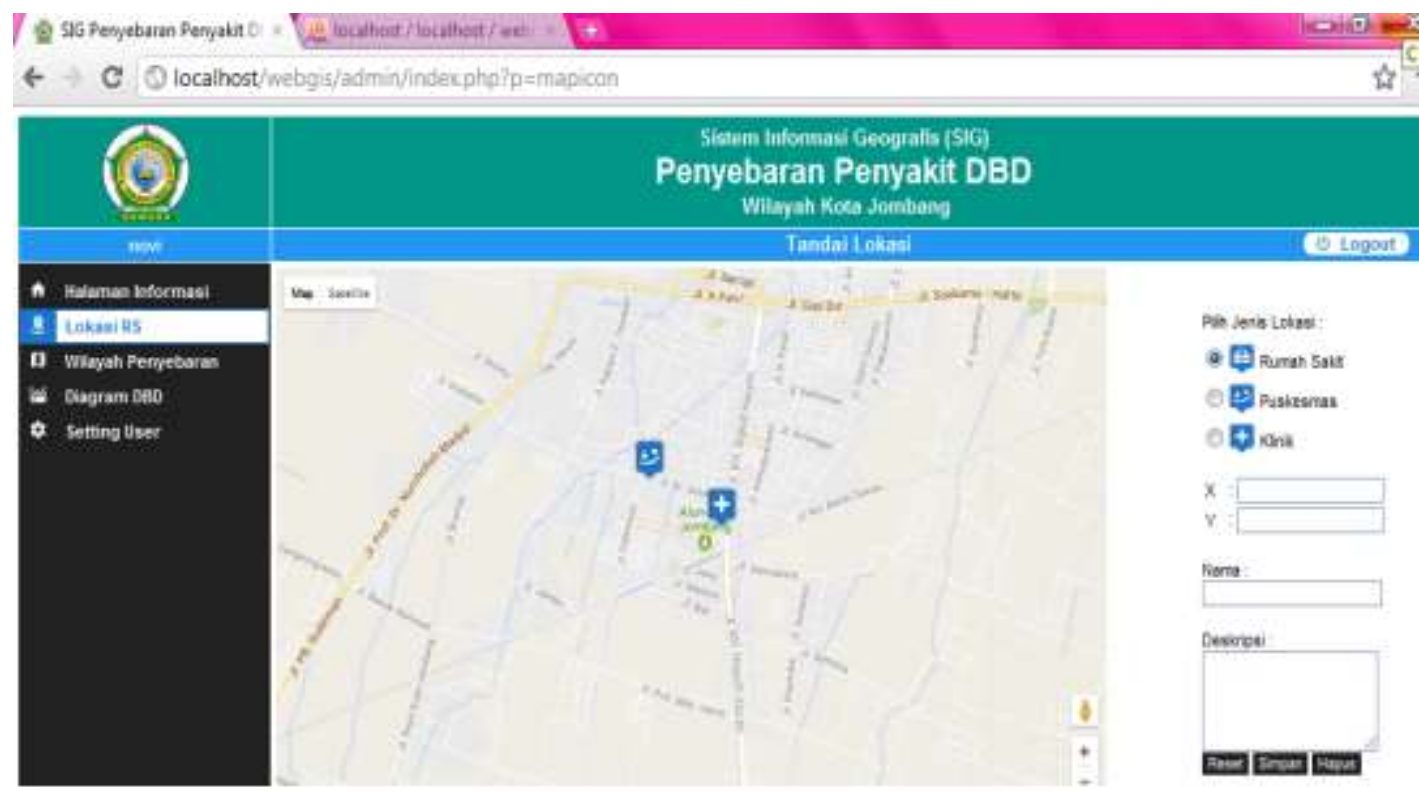

Gambar 5 : halaman menu edit letak RS 


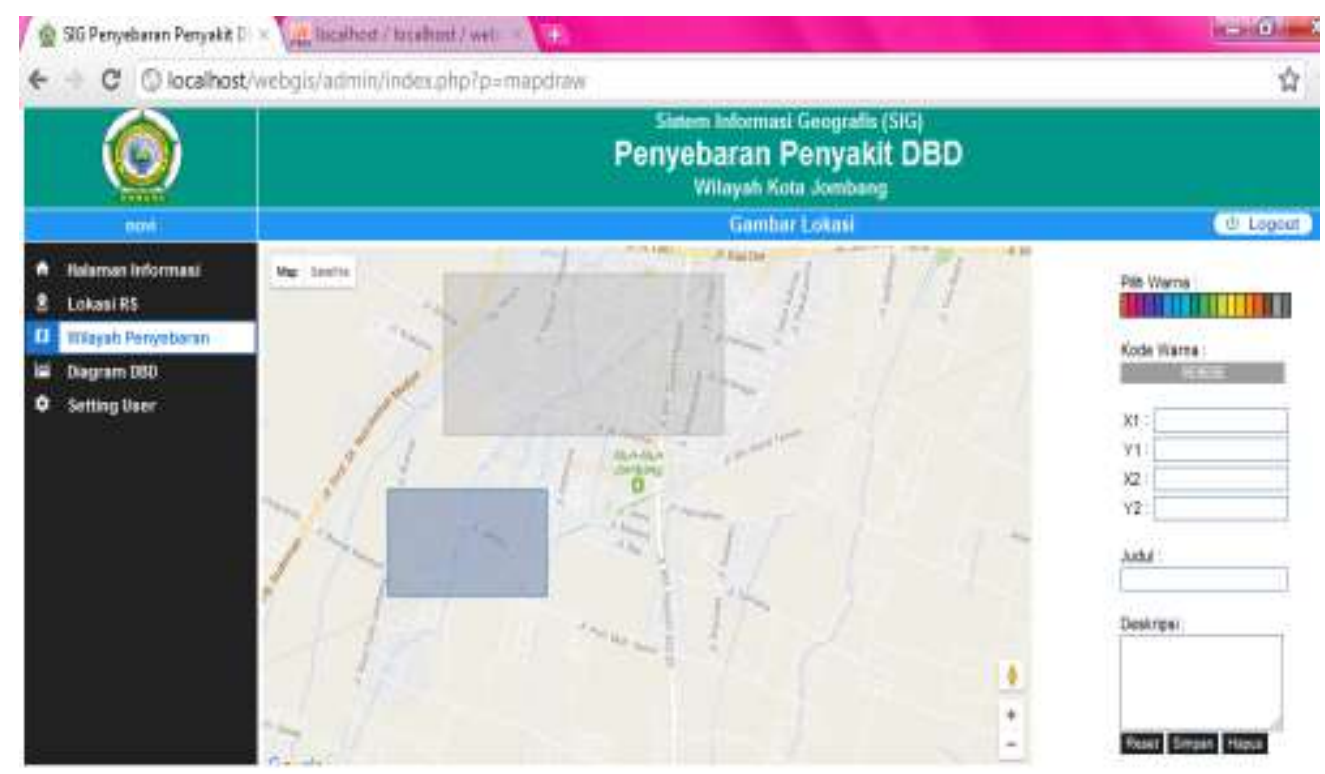

Gambar 6 : halaman menu edit wilayah penyebaran

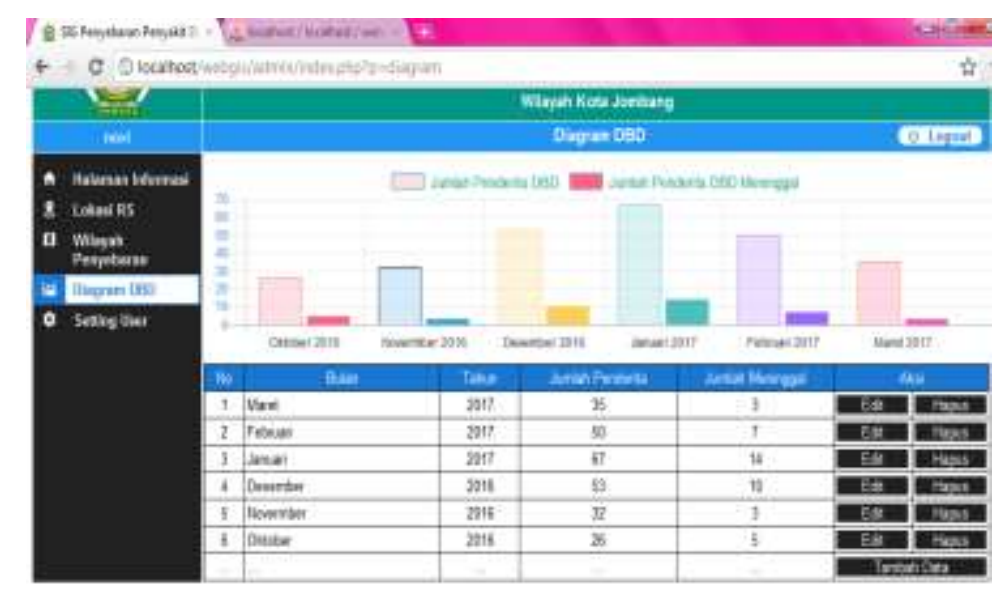

Gambar 7 : Halaman Edit Diagram

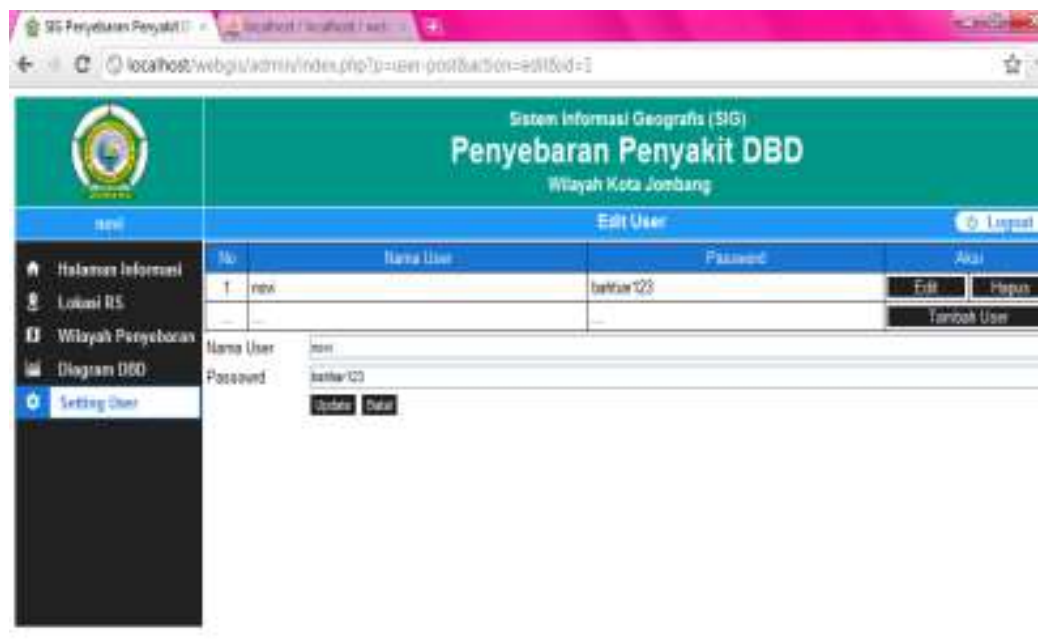

Gambar 8 : Halaman Menu Edit User 


\section{PENUTUP}

Pada Bab ini, peneliti juga memberikan kesimpulan dan saran yang berkaitan dengan judul penelitian yang diangkat, dengan tujuan untuk memberikan masukan bagi yang ingin mengembangkan aplikasi ini berkaitan dengan judul penelitian yang diangkat.

\subsection{Kesimpulan}

Pengembangan Perancangan aplikasi sistem informasi geografis penyebaran penyakit demam berdarah di jombang merupakan salah satu solusi untuk penyampaian informasi agar lebih efektif. Berikut ini adalah beberapa kesimpulan dari proses dan hasil penelitian:

- Pembuatan aplikasi sistem informasi geografis penyebaran penyakit demam berdarah dengue berbasis website ini diolah menggunakan xampp sebagai server lokal dan basis data MySql dengan fitur PhpMyadmin yang tersedia didalamnya dan browser sebagai pengecek tampilan yang dihasilkan;

- Pembuatan database aplikasi ini dilakukan dengan menggunakan mySQL dengan fitur PhpMyadmin dan aplikasi ini menyediakan informasi persebaran penyakit demam berdarah dengue dan informasi tersebut berupa jumlah penderita penyakit demam berdarah dengue 2016-2017.

\subsection{Saran}

Setelah memperhatikan kesimpulan dan hasil penelitian diatas, saran-saran yang dapat penulis sampaikan dalam Perancangan Sistem Informasi Geografis Penyebaran Penyakit Demam Berdarah Dengue adalah sebagai berikut :

- Bahwa program Perancangan Sistem Informasi Geografis Penyebaran Penyakit Demam Berdarah Dengue ini masih bisa dikembangkan lagi misalnya dengan penambahan menu saran dan kritik, tampilan yang menarik dan lebih baik, serta meningkatkan keamanan website.

- Perancangan Sistem Informasi Geografis Penyebaran Penyakit Demam Berdarah Dengue ini masih dapat dikembangkan lagi dengan pembuatan aplikasi berbasis mobile / android dimana admin dapat menginput data dengan mudah melalui android.

- Perancangan Sistem Informasi Geografis Penyebaran Penyakit Demam Berdarah Dengue, dapat dikembangkan dalam penambahan jenis penyakit, sehingga pembaca bisa sekaligus melakukan pencarian informasi penyakit lain. 


\section{DAFTAR PUSTAKA}

Kurniawan, Putu. 2014. Sistem Informasi Geografis Penyebaran Penyakit Berbasis WEB. Bali : Universitas Udayana

Athiyah, Umi. 2014. Aplikasi Sistem Informasi Geografis Penyebaran Penyakit Demam Berdarah Dengue Berbasis WEB. Kudus : Universitas Diponegoro

Candra, Aryu. 2010. Demam Berdarah Dengue Epidemiologi, Patogenesis, dan Resiko Penularan. Semarang : Universitas Diponegoro

Hamidi. 2012. Aplikasi Sistem Informasi Geografis Berbasis WEB Penyebaran Dana Bantuan Operasional Sekolah. Riau : Universitas Riau Pekanbaru 